\title{
Non-Performing Loans and Its Impact on Profitability: An Empirical Study on State Owned Commercial Banks in Bangladesh
}

\author{
Tanvir Hasan Anik*, Nandan Kumer Das, Md.Jahangir Alam \\ Begum Rokeya University, Rangpur, Bangladesh \\ Email: anik1120061@yahoo.com
}

\begin{abstract}
State owned commercial banks in Bangladesh have experienced catastrophe loan scams over the last decade. The frequent loan scams have made banking activities questionable. Therefore, non-performing loans must get proper consideration and supervision to lessen the occurrence of loan scams. This research paper examines the effect of non-performing loans on profitability of SCBs in Bangladesh. NPL ratio, NPL growth rate, deposit growth rate, provision growth rate and capital adequacy ratio have been taken as independent variables and return on equity (ROE) as dependent variables. Secondary data has been taken from FY 2005 to FY 2016 to analyze the impact of independent variables on dependent variable. The relationship has been tested using a multiple linear regression model. This paper shows that there is statistically significant negative relationship between non-performing loan ratio and return on equity. The model shows there is strong correlation between the independent variables and dependent variable with correlation coefficient of 0.933 . The overall model is statistically significant with p-value of 0.040 . The independent variables explain up to $71.3 \%$ variations in dependent variable ROE. This research also exposes that, NLP ratio, NLP growth rate, deposit growth rate, provision growth rate and liquidity ratio are adversely(Negatively) related to ROE. Whereas, capital adequacy ratio is positively related to ROE. The study inspects that, the relationship among NPL growth rate with ROE and capital adequacy ratio with ROE is statistically significant. On the other hand relationship among NPL ratio with ROE, deposit growth rate with ROE, provision growth rate with ROE and liquidity ratio with ROE is not statistically significant.
\end{abstract}

Keywords: Multiple linear regression model, provision growth rate, deposit growth rate.

\section{Introduction}

\subsection{Background of the Study}

In every economy banks play an important role in financial system. Providing loan is one of the most crucial activities that every bank should examine and monitor with outmost importance. Bank uses most of its funds to provide loans. These loans generate a significant portion of bank's revenue and profits. So procedures related to grant, disbursement and collection of interests and principal should engage careful observation. Otherwise substantial loss of banks' revenue can come forward. NPLs refer to those financial assets on which banks no longer have interest and/or installment payments as scheduled. They are considered as non-performing because the loan stops to "perform" or generate income for the bank. Choudhury et al. (2002) state that NPLs can be classified into different varieties usually grounded on the "length of overdue" of the said loans. NPLs can bring down investors' sureness in the banking system, heaping up unproductive economic resources even though depreciations are taken care of, and hindering the resource allocation process. In addition, NPLs, if created by the debtors willingly and left unresolved, might act as a contagious financial illness by driving good borrowers out of the financial market. Muniappan (2002) argues that a bank with high level of NPLs is forced to incur carrying costs on non-income yielding assets that not only strike at profitability but also at the capital adequacy of a bank, and in consequence, the bank faces difficulties in augmenting capital resources. NPL in Bangladesh has become a burning question in recent years. This problem has started to be widening with an evil trend of loan misappropriation among the industrial borrowers in our country. Frequent scam series in banking industry is surely a red light and unfortunately the state owned 
commercial banks are highly encircled by it. The amount of default loans of state owned commercial banks in Bangladesh has been increasing at a shocking rate. It is not a new issue but the tendency of fraud, misappropriation and loan default is in a serious situation in recent times due to excessive political intervention and illegal disruption of the concerns. The amount of total NPLs in the banking system of BD was Tk 523.1 billion at the end of 2013, that was 200.1 billion in 2006. Amount doubled within 8 years. This paper can aid to have a good idea of actual situation of loan management statistics of the SCBs and to take initiatives to come out of this fashion. It will save the SCBs from facing a noteworthy ratio of default risk, liquidity risk, reputational risk etc. The general people will feel secured; depositors will get their confidence back on those banks and may not be tempted to withdraw their deposits in fear of breakdown of banking sector like stock market crashing.

\subsection{Research Problem}

Non-performing loans have significant impact on bank's profitability measured by return on equity. Besides NPLs, there are other significant bank specific factors, namely, liquidity ratio, capital adequacy ratio, provision growth rate, deposit growth rate, expense to income ratio and so on. SCBs in Bangladesh hold the maximum portion of overall NPLs in the banking industry. This scenario is alarming as six state owned commercial banks cover lion's share of NPLs created by all scheduled banks registered under Bangladesh Bank (BB). In Bangladesh, SCBs recorded the highest 33.7\% of NPL ratio in FY 2002. In 2003, NPL ratio decreased to 29.0\%. It follows the decreasing trend up to 2005. For next two years, NPL ratio gradually increased. NPL ratio touched the minimum value of $11.3 \%$ in 2011 by SCBs in Bangladesh. In 2012, the ratio was drastically increased by $134.68 \%$. In recent years it has been observed that, the NPL to gross loan ratio is gradually increasing at a significant rate. Bangladesh Bank has formulated various guidelines regarding lending procedures and disbursement of loan tocurve the amount of non-performing loans. But unfortunately, SCBs didn't follow the guidelines for a decade. As a result, they experienced frequent loan scams that have put banking industry in complete shock. These frequent scenarios of loan scams have resulted in drastically fall in return on equity in recent years. In this research paper, relationship between NLPs and profitability measured in ROE has been analyzed.

\section{Literature Review}

\subsection{Global Empirical Literature Review}

Lending decision of a bank is very significant because it defines the future profitability and performance of the bank. Recently banks are becoming more conscious in customer selection to shun the negative effect of NPLs.. Amounts of bad loans are worryingly increasing in not only the developing and under developed countries but also in advanced countries. Banks' lending policy could have vital effect on NPLs. A default is not entirely an unreasonable decision. Rather a defaulter takes into account probabilistic assessment of various costs and benefits of his policy. According to Rajesh Parmer (2014) managing NPAs is a intimidating job for every bank in the financial sector. NPAs affect the position and performance of the banks in many magnitudes.

Kaaya and Pastory (2013) examined effect of credit risk (measured by ratios of nonperforming loan, loan loss to gross loan, loan loss to net loan and impaired loan to gross loan) on banks' performance (measured by return on assets) by controlling the influence of deposits and bank size. 11 banks in Tanzania have been used for this analysis. According to correlation and regression results, credit risk measures of non-performing loans, loan loss to gross loan, loan loss to net loan have noteworthy negative influence on banks' performance. It is established that performance of banks can be increased by effective risk management as it help to decrease NLPs and loan losses. Sameer \&Deepa (2013) expresses their opinion based on their analysis that the incidence of NPAs is affecting both the banks and financial institutions internally and financially. The willful nonpayers should be identified and treated well to recollect the funds.

Shingjergji (2013) studied the effect of different bank specific factors on NLPs of Albanian banks by taking quarterly data from 2002-2012. Dependent variable used in the analysis is NPLs while independent variables include loan to asset ratio, capital adequacy ratio, ROE, natural log of total loans, 
and natural log of net interest margin. Regression results obtained by using ordinary least square exposed negative trivial relation of CAR with NPLs. Relation of loan to asset ratio has been found negative but total loans level is positively manipulating the NPLs means increased loans level will result in bigger level of NPLs. On the other hand, NIM and ROE are adversely linked with NPLs which depicts that high NPLs deteriorate the performance of banks. Vatansever and Hepsen (2013) inspected the existence of any noteworthy relation (if exists) of non-performing loans with macroeconomic indicators, global and bank level factors in Turkey for a period of 2007 to 2013. Results obtained from OLS regression helped in categorizing the factors ominously affecting the NLPs.

As per Chatterjee, Mukherjee \& Das (2012) NPAs have a adverse influence on the achievement of Capital Adequacy level, Banking system credibility, Funds utilization and productivity on the overall economy. According to the analysis conducted by Dr. D. Ganesan and R. Santhanakrishnan the banks' profitability can be abridged only by effective management of NPAs. The NPAs of SBI has been continuously growing for over a decade but as the operations are more for SBI it is able to manage the profits. But still the corrective measures are to be specified to control NPAs.

NPLs are growing due to lack of risk management threatening the profitability of banks. This analysis provides proposition that banking sector can avoid their NPLs by implementing methods suggested by the central bank of respective country (Haneef \& Riaz, 2012). Louzis et al. (2012) used macroeconomic variables and bank factors, simultaneously, to inspect the determinants of NPLs in the banking sector. All the designated independent variables(Real GDP, Inflation ,Per Capita, and Total Loans as independent variables) have noteworthy influence on the depended variable(NPLs Ratio), however, values of coefficients are not much high. Banks should control and modify their credit advancement policy with respect to cited variables to have lower NPLs ratio (Saba, Kouser \& Azeem, 2012). Mohammed (2012) studied the bank performance in context of corporate governance for which mainly the ratios of NLPs and loan deposits have been used. Study was led on 9 banks of Nigeria for a period of 10 years from 2001-2010. According to generalized OLS regression results, non-performing loans ratio has noteworthy negative influence while loan deposit ratio has trivial negative effect on performance. Guy (2011) argued that NPLs have been widely used as a measure of asset quality among lending institutions and is often related with failures and financial crises in both the developed and developing world.

Reinhart and Rogoff (2010) as cited in Louzis et al., (2011) point out that non-performing loan can be used to mark the onset of a banking crisis. Greenidge and Grosvenor (2010) claimed that the magnitude of NPLs is a key element in the beginning and development of financial and banking crises. Lending is not an easy job for banks because it shaped a big problem calling NPLs (Upal, 2009). Due to the environment of their business, commercial banks showing themselves to the risks of default from borrowers and NPLs are meticulously related with banking crises (Waweru and Kalami, 2009). Inspite of ongoing struggles to control bank lending activities, NPLs are still a chief concern for both international and local regulators (Boudriga et al, 2009). Aziz et al., (2009) specified that the rising of NPLs has an influence on the financial institutions: they stiffened their lending and changed their attentions to rehabilitating the NPLs in their books.

According to Podpiera and Weill (2008) bank specific factors selected by each bank like cost efficiency, capitalization, activity diversification, performance and credit growth have an influence on the development of NPLs. Hou and Dickinson (2007), which scrutinized the NLPs on microeconomics, specifically at the bank level to empirically assess how NPLs affect commercial banks' lending pattern. In particular, it is discussing some consequences of NPLs on the economics.. Islam et al., (2005) claimed that NPLs, if created by the borrowers willingly and left unresolved, might act as a contagious financial malaise by driving good borrowers out of the financial market. Adhikary (2005) argued that the existence of an frightening amount of NPLs both in the Nationalized Commercial Banks (NCBs) and in the Development Financial Institutions (DFIs), along with maintenance of insufficient loan loss provisions, reduces the overall credit quality of Bangladesh. Poor implementation of laws relating to settlement of NPLs, followed by inadequate debt recovery measures on the part of the banks, has also worse the financial malady, although a decrease in NPLs is noticed since the year 2000. Loans therefore represented the majority of bank's assets (Saunders and Cornett, 2005). Although NPLs are adversely related to banks' profit efficiency, it is not statistically momentous (Fan and Shaffer, 2004).

Cargill et al., (2004) have recognized Japan's high level of NPLs as an outcome of protracted economic stagnation and deflation in the economy since the bursting of the "bubble" in the early 1990s. 
Lazy banking critically echoes on banks' investment portfolio and lending policy (Reddy \& Mohan, 2003). NPLs are regressed on three sets of factors in terms of credit, macroeconomic shocks and banks size induced risk preference. The panel regression models showed the terms of credit variables to be noteworthy. The estimated coefficient on changes in cost of credit because of anticipation of higher interest rate is affirmative. On the contrary, horizon of maturity of credit, better credit culture, and auspicious macroeconomic and business conditions decline the NPLs (Ranjan \& Dhal, 2003). Auronen (2003) stated that the theory of asymmetric information says that it may be hard to discriminate well from bad borrowers, which may result into adverse selection and moral hazards problems. The theory clarifies that in the market, the party that holds more information on specific item to be transacted (in this case the borrower) is in a position to negotiate optimum terms for the transaction than the other party (in this case, the lender). Adverse selection and moral hazards have led to large accumulation of NPLs in banks (Bofondi and Gobbi, 2003).

Muniappan (2002) claims that a bank with high level of NPLs is forced to experience carrying costs on non-income yielding assets that not only attack at profitability but also at the capital adequacy of a bank, and in consequence, the bank appearances difficulties in augmenting capital resources. There is no global standard to define NPLs at the practical level. Variations are in terms of the classification system, the scope, and contents. Such problem potentially augments to disorder and uncertainty in the NPL issues. NPLs have non-linear adverse effect on banks' lending pattern (Hou, 2001). Bonin and Huang (2001) also state that the probability of banking crises rise if financial risk is not eradicated quickly.

In Spain, Fernandez, Jorge and Saurina, (2000) concluded that despite bank supervisors being aware that most banking crises were directly associated with insufficient management of credit risk by respective institutions, it was hard for supervisors from central banks to pursue bank managers to follow more judicious credit policies during economic upturn, that even conservative managers might find market pressure for higher profits very hard to overcome. Choudhury et al., (1999) showed that Government directs the nationalized commercial banks to lend the profitable sector but helpful for marginal people, which turns into NLPs.

Islam et al., (1999) stated that the issue of NLPs in Bangladesh is not a new matter. In fact, the seeds were nurtured during the very early stage of the liberation period (1972-1981), by the government's "expansion of credit" policies on the one hand and a weak and infirm banking infrastructure combined with an unqualified work force on the other. Brownbridge (1998) concluded that many of the bad debts in banks were attributable to moral hazards; the adverse incentives on bank owners to adopt imprudent lending strategies, in particular insider lending at high interest rates to borrowers in the most risky segments of the credit market. Many studies on the causes of bank failures have found that institutions which face financial distress have higher proportions of NLPs prior to failure and that asset quality demonstrates a statistically significant forecaster of insolvency (Berger and De Young, 1997). Reed and Gill (1989) concluded that usually $85 \%$ of commercial banks income is made by interest on loans. According to the research by Havrilesky and Boorman (1976), interest on loans contributed meaningfully to interest income of commercial banks.

\section{Methodology and Econometric Model}

\subsection{Research Design}

This research paper is descriptive in nature. This paper investigates the impact of NLPs and other bank specific factors on state owned commercial banks in Bangladesh. Secondary data have been used to conduct the research. The study covered the time period of 12 years from 2005-2016. Profitability is measured by return on equity (ROE) taken as dependent variable. Independent variables are NPL ratio, NPL growth rate, deposit growth rate, capital adequacy ratio, provision growth rate and liquidity ratio.

\subsection{Population}

All the commercial banks listed in Bangladesh Bank (BB) are the population for this research work. There are 57 scheduled banks operating in our country as on 31st December, 2017. 


\subsection{Sample Size}

State owned commercial banks have been taken as the sample for the research. As the major portion of the total non-performing loan of banking industry is covered by the SCBs.

\subsection{Collection and Sources of Data}

This paper has used secondary data to investigate the relationship among variables. 12 consecutive years have been selected for the study from 2005-2016. The sources of data are Bangladesh Bank Library, annual reports of state owned commercial banks, articles and research papers from reputed journals.

\subsection{Data Analysis Tools}

Statistical Package for the Social Sciences (SPSS), version 22 has been used to analyze the data. Correlation matrix, Regression and ANOVA have been used to test the formed hypothesis.

\subsection{Specification of the Econometric Model}

The multiple linear regression model used in this research paper is as follows:

$$
\mathrm{ROE}=\alpha+\beta 1 \mathrm{NPLRt}+\beta 2 \mathrm{NPLGt}+\beta 3 \mathrm{CARt}+\beta 4 \mathrm{DPGt}+\beta 5 \mathrm{PRVGt}+\beta 6 \mathrm{LRt}+\varepsilon \mathrm{t}
$$

where,

$\alpha$ is constant;

$\beta 1$ to $\beta 6=$ Coefficient of determinants of return on equity (ROE);

$\mathrm{t}=$ Time interval $(1,2 \ldots .12)$;

$\varepsilon$ is error term.

\subsection{Research Hypotheses}

To analyze the impact of non-performing loan and bank specific factors on profitability measured by return on equity, the following alternatives hypothesis have been constructed and tested:

H1: There is significant relationship between NPL ratio and ROE.

H2: There is significant relationship between NPL growth rate and ROE.

H3: There is significant relationship between $C A R$ and $R O E$.

H4: There is significant relationship between deposit growth rate and $R O E$.

H5: There is significant relationship between provision growth rate and $R O E$.

H6: There is significant relationship between liquidity ratio and ROE.

\section{Analysis and Findings}

This research paper includes two parts in analysis. In first part introduction of the banking system structure, capital adequacy ratio, NPLs ratio, ratio of net NPL to total loans, amount of NPL, maintained provision, profitability ratios, net interest income, liquidity ratio and trends of deposits and advance in the banking system are represented and comparative scenario has also been made among SCBs, PCBs and FCBs.

\subsection{Comparative Scenario Analysis}

There are several research regarding identification, measurement, causes and effect of NPLs done many scholars of our country in different periods of time. SCBs in our country hold a significant portion of total deposits of the entire industry but it is a matter of great regret that those banks experience frequent default of loan recovery and scams to a large extent.

There are 57 scheduled banks operating in our country. As on 30th June there are 6 SCBs in our country. SCBs hold the maximum proportion of branches in comparing with other banks. SCBs hold 3339.79 billion BDT as deposits. Where maximum deposits are being hold with PCBs worth 8136.32 billion BDT. 26.99\% share of industry assets belongs to SCBs. In addition 28.31\% share of whole 
deposits hold with SCBs. Hence SCBs have a major role in banking industry. But frequent scams of SCBs have made its role questionable.

Table 1. Information of the banking system structure

\begin{tabular}{c|ccccc|c}
\hline \multirow{2}{*}{ Bank } & \multicolumn{5}{|c|}{ 2017- June } & (billion BDT) \\
\cline { 2 - 7 } Types & No. of & No. of & Total & Share of Industry & \multirow{2}{*}{ Deposits } & Share of \\
Banks & Branches & Assets & Assets & & Deposits \\
\hline SCBs & 6 & 3713 & 3339.79 & $26.99 \%$ & 2654.14 & $28.31 \%$ \\
PCBs & 40 & 4529 & 8136.32 & $65.76 \%$ & 6080.05 & $64.85 \%$ \\
FCBs & 9 & 71 & 582.33 & $4.72 \%$ & 377.71 & $4.03 \%$ \\
DFIs & 2 & 1407 & 313.49 & $2.53 \%$ & 263.58 & $2.81 \%$ \\
\hline Total & 57 & 9720 & 12371.94 & $100 \%$ & 9375.48 & $100 \%$ \\
\hline
\end{tabular}

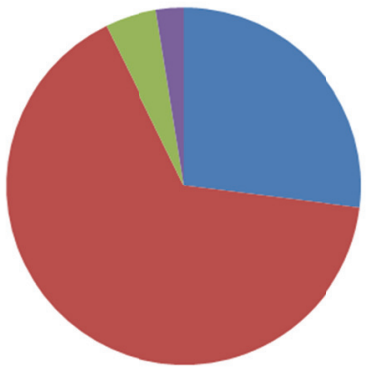

- SCBS

- $\mathrm{PCBS}$

FCBS

DFIS

Figure 1. Share of industry assets

The above chart shows that maximum share of industry assets belongs to PCBs. SCBs secure second position with a $26.99 \%$ share of industry assets. Whereas FCBs and DFIs hold third and fourth position respectively.

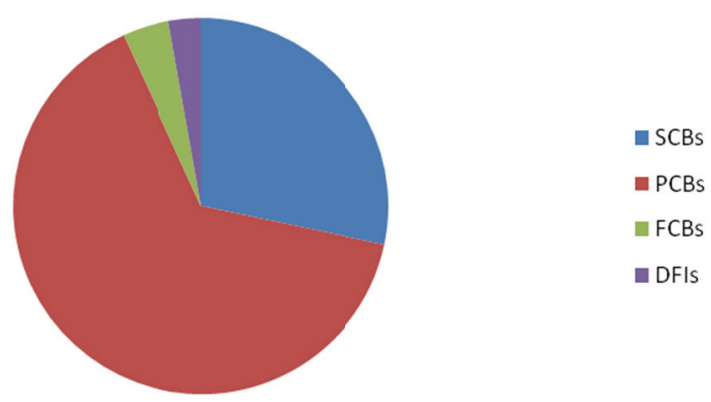

Figure 2. Share of deposits

Deposits play an important role in banking sector. Because deposits provide the necessary fund required to make loan. Banks' profitability largely depends on its loan disbursement. So collection of deposits should be given much priority. SCBs, PCBs, FCBs and DFIs contain 28.31\%, 64.85\%, 4.03\% and $2.81 \%$ share of deposits respectively.

NLP Rate is the most important issue for banks to survive. There are lots of factors accountable for this ratio. Some of them belong to firm level issues and macroeconomic measures. Capital to risk weighted assets of SCBs for the selected 5 years is not satisfactory. In FY 2012 it was $8.1 \%$ and in FY 2013 it reached up to $10.8 \%$.In the following years the ratio gradually decreased. It reached to the lowest value of $5.9 \%$ in 2016. The ratio was gradually decreasing from 2014 to 2016. If we create an appraisal the ratio of SCBs with PCBs and FCBs then we easily have a vibrant idea about the competitive situation. The bottommost value of PCBs and FCBs are $11.4 \%$ and $20.2 \%$. 


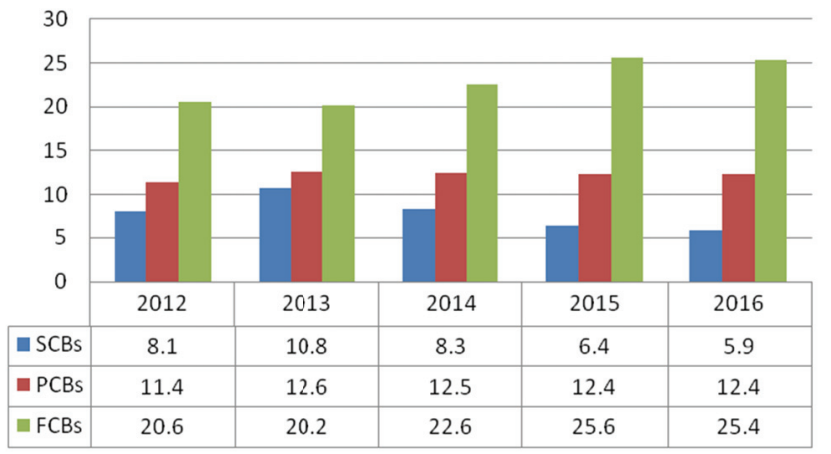

Source: Banking Performance Indicators, Appendix-4 (Table Ii), Banking Regulation \& Policy Department, Bangladesh Bank, (2012-2016).

Figure 3. Capital of risk weighted asset ratio \%

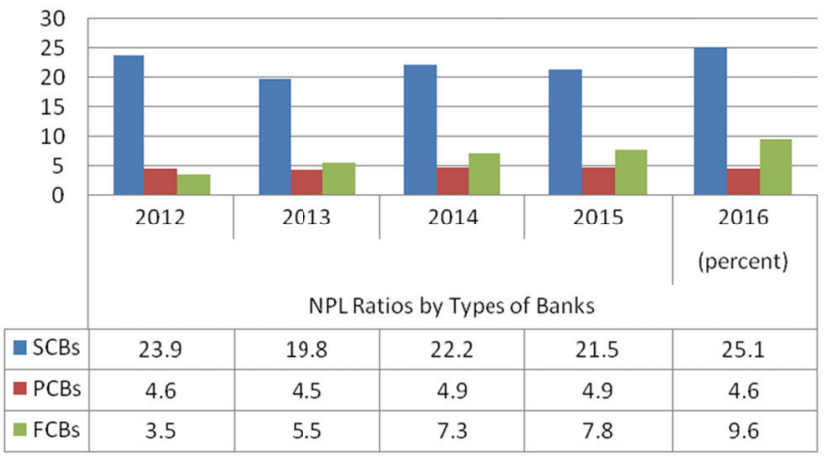

Source: Banking Performance Indicators, Appendix-4 (table 4), Banking Regulation \& Policy Department, Bangladesh Bank, (2012-2016).

Figure 4. NPL to total loan ratio

NPL is a common factor for banking and it is acceptable up to a certain limit. How much loans are being non-performing every year is a pertinent measurement in this regard. Non performing loans to total loans ratio for SCBs for selected 5 years is really frightening as most of the years it grips more than 20\% NPLs as per Total Loans and Advances. In FY 2012 the ratio was 23.9\%. In next year the ratio reduced to $19.8 \%$. The ratio hit the peak $25.1 \%$ in FY 2016 . We can see that over the 5 years period the ratio followed an increasing trend. If we make a comparison among three categories of banks we find that PCBs had maximum NPL ratio in 2014 and over the 5 years they maintained the ratio within $5 \%$.On the other hand the performance of FCBs is not satisfactory. As their NPL ratio gradually increased over the years and hit a peak $9.6 \%$ in 2016 .

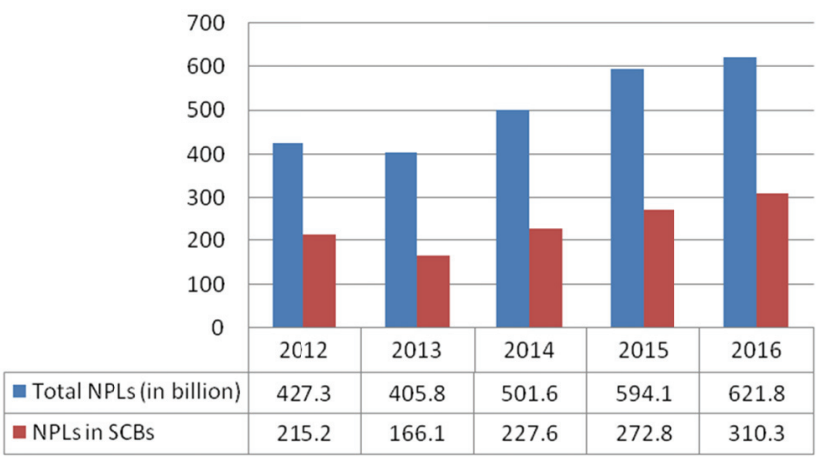

Source: Banking Performance Indicators, Appendix-4 (Table V), Banking Regulation \& Policy Department, Bangladesh Bank, (2012-2016).

Figure 5. Comparative position of NPLs 
From the above depicted graph it has been seen that SCBs grip the maximum portion of the total NPLs in banking industry over the selected years which was from 2012 to 2016. Among them in 2016, the industry evidenced the largest amount of NPLs that was BDT 310.3 billion. There be present a consistent harmony in NPLs amount depicting that there is very poor initiative in controlling process and recovery process of those banks.

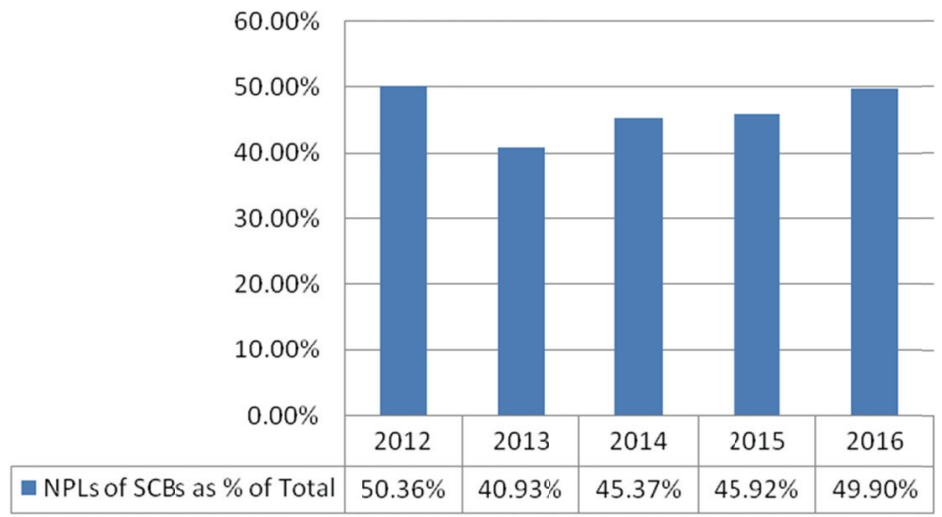

Source: Banking Performance Indicators, Appendix-4 (Table V), Banking Regulation \& Policy Department, Bangladesh Bank, (2012-2016).

Figure 6. NPLs of SCBs as \% of total

From the above graph, we can see that in FY 2012 SCBs hold 50.36\% share of total NPLs which is the highest among the years. In 2013 it reduces to 40.93\%. Then the ratio gradually increased for rest of the years.

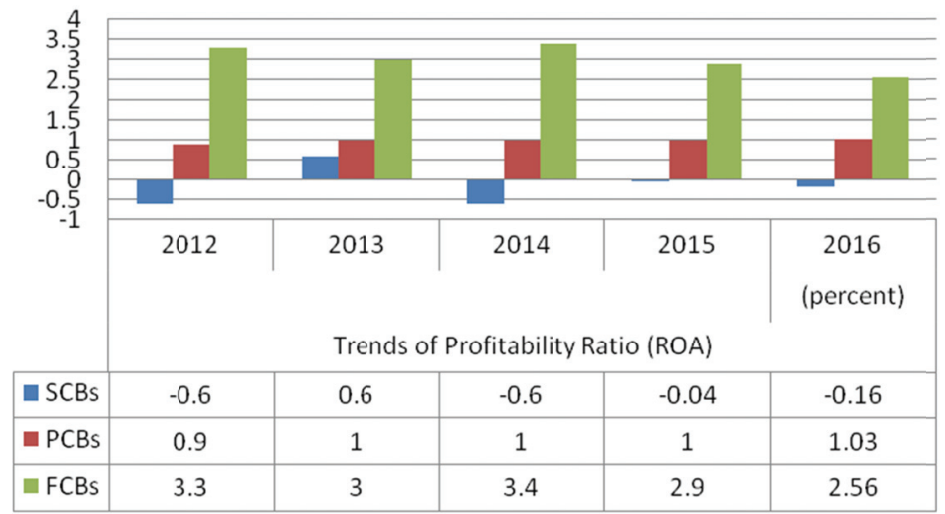

Source: Banking Performance Indicators, Appendix-4 (Table X), Banking Regulation \& Policy Department, Bangladesh Bank, (2012-2016).

Figure 7. Trends of profitability ratio (ROA)

The graph depicts the profitability ratio of SCBs in our country. In 2013 ROA for SCBs was positive having $0.6 \%$ and rest of the years holds negative ROA. Whereas PCBs performed much better in comparison to SCBs. Over the five years PCBs maintained their ROA ratio around 1\%.FCBs performance was pretty good. They achieved the highest ROA of 3.4\% in FY 2014 and lowest ROA of $2.56 \%$ in 2016 . Over the five years they maintained satisfactory positive ROA. 


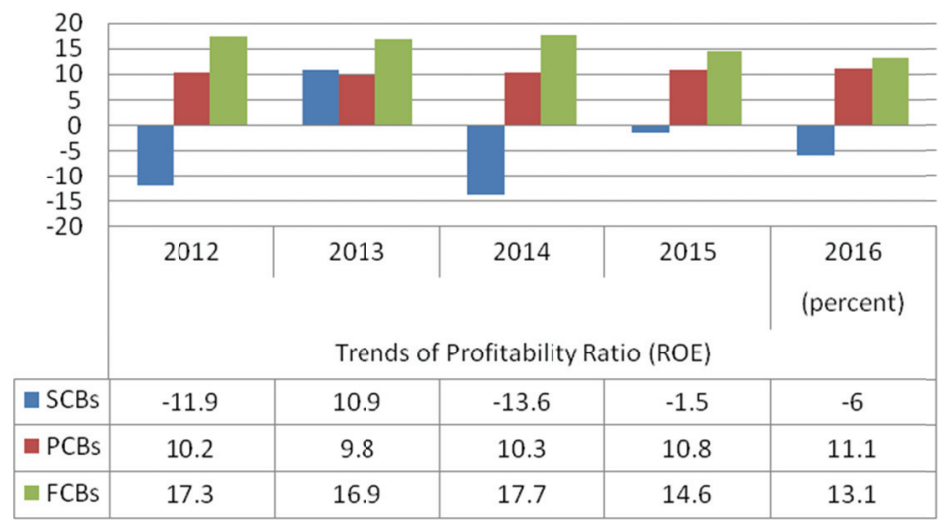

Source: Banking Performance Indicators, Appendix-4 (Table X), Banking Regulation \& Policy Department, Bangladesh Bank, (2012-2016).

Figure 8. Trends of profitability ratio (ROA)

The ROE ratio of SCBs wasn't Satisfactory at all. Except in 2013, the ROE ratios were negative. The highest ROE ratio was 10.9\% in FY 2013 and the lowest ROE ratio was -13.6\% in 2014. In comparison the performance of PCBs and FCBs is much satisfactory. Over all the five years they maintained positive ROE ratio. PCBs had the highest ROE ratio of $11.1 \%$ in 2016 and lowest $9.8 \%$ in 2013 . FCBs had the highest ROE ratio of $17.7 \%$ in 2014 and lowest $13.1 \%$ in 2016.

\subsection{Statistical Analysis and Findings}

\subsubsection{Descriptive statistics}

Table 2. Descriptive statistics of variables used in the regression model

\begin{tabular}{lccccc}
\hline & $\mathrm{N}$ & Minimum & Maximum & Mean & Std. Deviation \\
\hline ROE & 12 & -13.6 & 26.2 & 4.817 & 14.0524 \\
NPLG & 12 & -22.82 & 134.68 & 14.9317 & 41.51852 \\
NPLR & 12 & 11.3 & 29.9 & 21.708 & 4.7387 \\
CAR & 12 & -.4 & 11.7 & 7.050 & 3.5544 \\
DPG & 12 & 5.28 & 20.23 & 13.3933 & 5.14905 \\
PRVG & 12 & -30.00 & 288.24 & 52.5267 & 95.91133 \\
LR & 12 & 20.0 & 44.3 & 31.533 & 8.6174 \\
\hline
\end{tabular}

Source: Results obtained by the researcher (SPSS output)

The descriptive statistics of selected variables used in the empirical analysis is presented in Table 2 . The mean value of ROE is $4.817 \%$ having minimum and maximum value of $-13.6 \%$ and $26.2 \%$ respectively. Variable NPLG represents high variability as it ranges from $-22.82 \%$ to $134.68 \%$. Mean value of NPLG is $14.9317 \%$ with standard deviation of $41.51852 \%$. NPLR has mean value of $21.708 \%$, it presents a low variability as having standard deviation of $4.7387 \%$. CAR has standard deviation of $3.5544 \%$ and mean is $7.050 \%$. It has minimum value of $-.40 \%$. DPG also represents a low variability with standard deviation of $5.14905 \%$. It ranges from $20.23 \%$ to $13.3933 \%$. PRVG has the highest dispersion around its mean. It holds standard deviation of $95.91133 \%$, having minimum value $-30.00 \%$ and maximum value $288.24 \%$. Lastly variable LR has mean value of $31.533 \%$. It ranges from $20.0 \%$ to $44.3 \%$.

\subsubsection{Correlation matrix}

The correlation matrix of variables used in the model is presented in Table 3 using Pearson analysis. Analysis shows that ROE has positive correlation with CAR $(r=0.444)$, DPG $(r=0.202)$. In addition analysis shows ROE has negative correlation with NPLR $(\mathrm{r}=-.426)$, NPLG $(\mathrm{r}=-.648)$, PRVG $(\mathrm{r}=-$ 
$.289)$ and LR ( $\mathrm{r}=-.138)$. Dependent variable ROE has statistically significant correlation with independent variable NPLG at 0.05 level of significant (1 tailed). Some statistically significant correlation was found among the independent variable. DPG with NPLR $(\mathrm{r}=-.691)$, DPG with CAR $(\mathrm{r}$ $=0.668)$, PRVG with CAR $(\mathrm{r}=-.534)$, LR with CAR $(\mathrm{r}=0.501)$, PRVG with DPG $(\mathrm{r}=-.523)$, LR with DPG $(\mathrm{r}=0.578)$ and LR with PRVG $(\mathrm{r}=-.497)$. All these correlation coefficient is significant at 0.05 level of Significant (1 tailed).

Table 3. Correlations among selected variables

\begin{tabular}{|c|c|c|c|c|c|c|c|c|}
\hline & & $\mathrm{ROE}$ & NPLR & NPLG & CAR & $\mathrm{DPG}$ & PRVG & LR \\
\hline \multirow{7}{*}{$\begin{array}{l}\text { Pearson } \\
\text { Correlation }\end{array}$} & $\mathrm{ROE}$ & 1.000 & & & & & & \\
\hline & NPLR & -.426 & 1.000 & & & & & \\
\hline & NPLG & $-.648^{*}$ & .351 & 1.000 & & & & \\
\hline & CAR & .444 & -.359 & -.062 & 1.000 & & & \\
\hline & DPG & .202 & $-.691^{*}$ & -.194 & $.668^{*}$ & 1.000 & & \\
\hline & PRVG & -.289 & .383 & -.073 & $-.534 *$ & $-.523 *$ & 1.000 & \\
\hline & LR & -.138 & -.059 & -.034 & $.501^{*}$ & $.578^{*}$ & $-.497 *$ & 1.000 \\
\hline
\end{tabular}

*Correlation is significant at the 0.05 level ( 1 tailed)

Source: Results obtained by the researcher (SPSS output)

\subsubsection{Model testing}

Table 4. Model summary**

\begin{tabular}{|c|c|c|c|c|c|}
\hline Model & $\mathrm{R}$ & R Square & Adjusted R Square & Std. Error of the Estimate & Durbin-Watson \\
\hline 1 & $.933^{\mathrm{a}}$ & .870 & .713 & 7.5260 & 2.165 \\
\hline \multicolumn{6}{|c|}{$\begin{array}{l}\text { a. Predictors: (Constant), LR, NPLG, NPLR, CAR, PRVG, DPG } \\
\text { b. Dependent Variable: ROE }\end{array}$} \\
\hline
\end{tabular}

Table 4 shows the model summary of the regression analysis. The coefficient of correlation $(\mathrm{R})$ of the model is 0.933 , which states that there is a strong relationship between dependent variable (ROE) and all the independent variables. The coefficient of determination ( $\mathrm{R}$-square) is 0.870 , states that the independent variables explain the highest $87.0 \%$ variability in dependent variable (ROE). The adjusted $\mathrm{R}$-square value is 0.713 explains that if other independent variables are incorporated in the model $71.3 \%$ of variations in dependent variable (ROE) can be explained by the independent variables. The DurbinWatson statistic is 2.165; this indicates that there is no auto-correlation among the independent variables.

Table 5. ANOVA**

\begin{tabular}{l|lccccc}
\hline \multicolumn{1}{c}{ Model } & Sum of Squares & DF & Mean Square & F & P-Value \\
\hline \multirow{3}{*}{1 Regression } & 1888.974 & 6 & 314.829 & 5.558 & $.040^{*}$ \\
& Residual & 283.202 & 5 & 56.640 & & \\
& Total & 2172.177 & 11 & & & \\
\hline a. Dependent Variable: ROE & & & & \\
b. Predictors: (Constant), LR, NPLG, NPLR, CAR, PRVG, DPG & \\
\hline
\end{tabular}

Table 5 shows the statistics for ANOVA. The F- statistic and the P-value for the regression model are 5.558 and 0.040 respectively. The p-value is less than 0.05 level of significant. This indicates that the overall model is statistically significant. That is, liquidity ratio, NPL growth rate, NPL ratio, capital 
adequacy ratio, provision growth rate and deposit growth rate have significant impact on return on equity.

Table 6. Coefficients*

\begin{tabular}{|c|c|c|c|c|c|c|}
\hline & \multirow{2}{*}{ Model } & \multicolumn{2}{|c|}{ Unstandardized Coefficients } & \multirow{2}{*}{$\begin{array}{c}\text { Standardized Coefficients } \\
\beta\end{array}$} & \multirow{2}{*}{$\mathrm{t}$} & \multirow{2}{*}{ Sig. } \\
\hline & & $\beta$ & Std. Error & & & \\
\hline \multirow{7}{*}{1} & (Constant) & 32.791 & 22.754 & & 1.441 & .209 \\
\hline & NPLR & -.102 & .918 & -.034 & -.111 & .916 \\
\hline & NPLG & -.237 & .061 & -.699 & -3.846 & .012 \\
\hline & CAR & 2.461 & .918 & .623 & 2.681 & .044 \\
\hline & DPG & -.784 & 1.022 & -.287 & -.768 & .477 \\
\hline & PRVG & -.058 & .033 & -.396 & -1.782 & .135 \\
\hline & LR & -.826 & .434 & -.506 & -1.901 & .116 \\
\hline
\end{tabular}

Source: Results obtained by the researcher (SPSS output)

The constant coefficient is 32.791 , which states that the mean value of ROE is $32.791 \%$ when all independent variables remain constant (0). The slope coefficient of NPLR is -.102, states negative relationship with ROE. If NPLR increases by $1 \%$, ROE will be decreased by $0.102 \%$. The significance is greater than 0.05. So, null hypothesis is accepted and alternate hypothesis $H 1$ is rejected. NPLG has slope coefficient of -.237 , states that if NLPG increases by $1 \%$, ROE will be decreased by $0.237 \%$. Thus it refers to negative relationship. The significance is less than 0.05. So, null hypothesis is rejected and alternate hypothesis H2 is accepted. CAR has coefficient of 2.461, denotes positive relationship with ROE. If CAR increases by $1 \%$, ROE will be increased by $2.461 \%$. The null hypothesis is rejected and alternate hypothesis $H_{3}$ is accepted, as its significance level is less than 0.05. DPG has negative relationship with ROE, as the slope coefficient is -.784. ROE will be decreased by $0.784 \%$ if DPG increases by $1 \%$. The significance level is 0.477 which is greater than 0.05 . Thus alternate hypothesis $H 4$ is rejected and null hypothesis is accepted. PRVG holds slope of -.058, states negative relationship with ROE. If PRVG increases by $1 \%$, ROE will be decreased by $0.058 \%$. It has significance level of 0.135 , which is greater than 0.05 . So, null hypothesis is accepted and alternate hypothesis H5 is rejected. LR has slope coefficient of -.826 . Therefore, LR has negative relationship with ROE. There will be $0.826 \%$ decrease in ROE, if LR increases by $1 \%$. The significance level is more than 0.05 . Therefore, alternate hypothesis $H 6$ is rejected and null hypothesis is accepted.

Hence, the following regression model predicts ROE of SCBs with $71.3 \%$ explanatory power.

$$
\mathrm{ROE}=32.791-.102 \mathrm{NPLRt}-.237 \mathrm{NPLGt}+2.461 \mathrm{CARt}-.784 \mathrm{DPGt}-.058 \text { PRVGt }-.826 \mathrm{LRt}+\varepsilon \mathrm{t}
$$

\subsubsection{Analysis of findings}

As per fiancé theory higher NPL ratio, NPL growth rate, deposit growth rate, provision growth rate and liquidity ratio will result in lower return on equity. In this research paper, the similar impact of NPL ratio, NPL growth rate, deposit growth rate, provision growth rate and liquidity ratio on return on equity is found. The rejection of $\mathrm{H} 1, \mathrm{H}_{4}, \mathrm{H} 5$ and $\mathrm{H} 6$ hypothesis states that the relationship among NLPR with ROE; DPG with ROE; PRVG with ROE and LR with ROE is not statistically significant. However, the acceptance of $H_{2}$ and $H_{3}$ states that there is statistically significant relationship among NPLG with ROE and CAR with ROE. The summary of tested hypotheses is presented in the above table.

This research paper shows that there is no significant relationship between NPL ratio with return on equity; deposit growth rate with return on equity; provision growth rate with return on equity and liquidity ratio with return on equity. In addition, there is significant relationship between NPL growth rate with return on equity and capital adequacy ratio with return on equity. 
Table 7. Analysis of findings

\begin{tabular}{cccc}
\hline Hypotheses & Symbol & Accepted/Rejected & Significance (0.05) \\
\hline H1 & NPLR & Rejected & Not \\
H2 & NPLG & Accepted & Yes \\
H3 & CAR & Accepted & Yes \\
H4 & DPG & Rejected & Not \\
H5 & PRVG & Rejected & Not \\
H6 & LR & Rejected & Not \\
\hline
\end{tabular}

\section{Conclusions and Recommendations}

To analyze the relationship between non-performing loans and profitability of SCBs in Bangladesh a multiple linear regression model has been used. I have found strong correlations among the variables used in the model. This research paper demonstrated that NPL ratio, NPL growth rate, deposit growth rate, provision growth rate and liquidity ratio have negative impact on return on equity. On the other hand, capital adequacy ratio has significant positive relationship with dependent variable ROE. I have found through the analysis of regression model that NPL growth rate and capital adequacy ratio have statistically significant impact on return on equity. In contrast, NPL ratio, deposit growth rate, provision growth rate and liquidity ratio have impact on return on equity but isn't statistically significant.

\section{References}

1. Adhikary, B.K. (2006). Nonperforming loans in the banking sector of Bangladesh: realities and challenges. Bangladesh Institute of Bank Management, 75-95.

2. Ahmad, F., \& Bashir, T. (2013). Explanatory Power of Bank Specific variables as Determinants of NonPerforming Loans: Evidence from Pakistan Banking Sector, World Applied Sciences Journal, 9(22).

3. Angbazo, L. (1997). Commercial Bank Net Interest Margins, Default Risk, Interest-Rate Risk and Off-Balance Sheet Banking. Journal of Banking and Finance, 21(1), 55-87.

4. Angklomkliew, S., George, J., \& Packer, F. (2009). Issues and developments in loan loss provisioning: the case of Asia. BIS Quarterly Review, 69-83.

5. Berger, A.N., \& DeYoung, R. (1997). Problem loans and cost efficiency in commercial banks. Journal of Banking and Finance, 21(6), 849-870.

6. Bonin, J.P., \& Huang, Y. (2001). Dealing with the bad loans of the Chinese banks. Journal of Asian Economics, $12(2), 197-214$.

7. Boudriga, A., Taktak, N.B., \&Jellouli, S. (2009). Banking supervision and non-performing loans: a crosscountry analysis. Journal of Financial Economic Policy, 1(4), 286-318.

8. Cargill, T.F., \& Parker, E. (2004). Price Deflation, Money Demand, and Monetary Policy Discontinuity: A Comparative view of Japan, China, and the United States. The North American Journal of Economics and Finance, 15(1), 125-147.

9. Choudhury, T., Ahmed, \& Moral, L.H. (1999). Commercial Bank Restructuring in Bangladesh: From FSRP to BRC/ CBRP. Bank Parikrama, 22-31.

10. Demirguc-Kunt, A., \& H. Huizinga, H. (1999). Determinants of Commercial Bank Interest Margins and Profitability: Some International Evidence, World Bank Economic Review, 13, 379-408.

11. Greenidge, K., \& Grosvenor, T. (2010). Forecasting non-performing loans in Barbados. Journal of Business, Finance and Economics in Emerging Economies, 5(1), 80-107.

12. Guy, K., \& Lowe, S. (2011). Non-performing loans and bank stability in Barbados. Economic Review, 37(1), 7782.

13. Haneef, S., \&Riaz, T. (2012). Impact of Risk Management on Non-Performing Loans and Profitability of Banking Sector of Pakistan. International Journal of Business and Social Science, 3(7).

14. Havrilesky, T.M., \&Boorman, J.T. (1976). Current issues in monetary theory and policy (2nd ed.).

15. Hou, Y. (2001). The Non-performing Loans: Some Bank-level Evidences. Journal of Banking and Finance, 25-46. 16. Hou,Y., \& Dickinson, D. (2007). The non-performing loans: some bank-level evidences. In 4th International 
Conference on Applied Financial Economics, Samos Island, Greece.

17. Islam, Muinul, \& Moral, L., (1999). Bank Loan Default Problem in Bangladesh: A dialogue between Borrowers and Lenders. Keynote paper (seminar paper) presented at Bangladesh Institute of Bank Management, published in Bank Parikrama, 22-31, 35-37.

18. Islam, Shofiqul, M., Chandra, S.N., \&Mannan, M.A. (2005). Non-Performing loans- its causes, consequences and some learning. Munich Personal RePEc Archive.

19. Kaaya, I., \&Pastory, D. (2013). Credit Risk and Commercial Banks Performance in Tanzania: a Panel Data Analysis. Research Journal of Finance and Accounting, 4(16), 55-62.

20. Kwack, Sung Yeung. (2000). An Empirical Analysis of the Factors Determining the Financial Crisis in Asia. Journal of Asian Economics, 11(2), 195-206.

21. Khalid, A. C. (2012). The impact of Asset Quality on Profitability of Private Banks in India: A Case Study of JK, ICICI, HDFC \& YES Banks, Journal of African Macroeconomic review, ISSN 2220-945X. 2(1).

22. Louzis, D., Vouldis, A., \& Metaxas, V. (2012). Macroeconomic and bank-specific determinants of nonperforming loans in Greece: A comparative study of mortgage, business and consumer loan portfolios. Journal of Banking \& Finance, 36(4), 1012-1027.

23. Marki, V., Tsagkanos, A., \&Bellas A. (2014). Determinants of Non-Performing Loans: The Case of Eurozone. Panoeconomicus, 61(2), 193-206.

24. Michael, JN., Vasanthi, G., \&Selvaraju, R. (2006). Effect of Non-Performing Assets on operational Efficiency of Central-Cooperative Banks. Indian Economic Panorama, 6(3), 33-39.

25. Mohammed, F. (2012). Impact of Corporate Governance on Banks Performance in Nigeria. Journal of Emerging Trends in Economics \& Management Sciences, 3(3), 257-260.

26. Muniappan, G.P. (2002). The NPA Overhang-Magnitude, Solutions, Legal Reforms. Reserve Bank of India Bulletin, 18-19.

27. Podpiera, J., \& Weill, L. (2008). Bad luck or bad management? Emerging banking market experience. Journal of Financial Stability, 4(2), 135-148.

28. Rajan, R., \& Dhal, S.C. (2003). Non-performing loans and terms of credit of public sector banks in India: An empirical assessment. Reserve Bank of India Occasional Papers, 24(3), 81-121.

29. Rajput, N., Gupta, M., \& Chauhan, M. A. K. (2012). Profitability and credit culture of NPAs: An empirical analysis of PSBs. International Journal of Marketing, Financial Services \& Management Research, 1(9), 91-109.

30. Reed, E.W., \& Gill, E.K. (1989). Commercial Banking (4th ed.). Prentice Hall, New Jersey, USA.

31. Richard, E. (2011). Factors That Cause Non-Performing Loans in Commercial Banks in Tanzania and Strategies to Resolve Them. Journal of Management Policy and Practice, 12(7).

32. Saba, I., Kouser, R., \&Azeem, M. (2012). Determinants of Non-Performing Loans: Case of US Banking Sector, 44 .

33. Saunders \& Cornett. (2005). Financial Institution Management, McGraw Hill Publishing.

34. Shingjergji, A. (2013). The Impact of Bank Specific Variables on the Non-Performing Loans Ratio in the Albanian Banking System. Research Journal of Finance and Accounting, 4(7), 148-152.

35. Sinkey, J.F., \& Mary, B.G. (1991). Loan-Loss Experience and Risk-Taking Behavior at Large Commercial Banks. Journal of Financial Services Research, 5, 43-59.

36. Sufian, F. \& Chong, R. R. (2008). Determinants of Bank Profitability in a Developing Economy: Empirical Evidence from Philippines. Asian Academy of Management Journal of Accounting and Finance, 4(2), 91-112.

37. Uppal, R.K. (2009). Priority sector advances: Trends, issues and strategies. Journal of Accounting and Taxation, $1(5), 79-89$.

38. Vatansever, M., \&Hepsen, A. (2013). Determining Impacts on Non-Performing Loan Ratio in Turkey. Journal of Finance and Investment Analysis, 2(4), 119-129.

39. Waweru, N., \&Kalani, V.M. (2009). Commercial banking crises in Kenya: Causes and remedies. African Journal of Accounting, Economics, Finance and Banking Research, 4(4), 12-33.

\title{
Acronyms
}

\author{
NII $=$ Net Interest Income \\ NPLR $=$ Non Performing Loan Ratio \\ DPGR $=$ Deposit Growth Rate \\ NPLG $=$ Non Performing Loan Growth Rate
}


PRVG $=$ Provision Growth Rate

$\mathrm{SCBs}=$ State Owned Commercial Banks

$\mathrm{PCBs}=$ Private Commercial Banks

$\mathrm{FCBs}=$ Foreign Commercial Banks

$\mathrm{ROE}=$ Return on Equity

ANOVA $=$ Analysis of Variance

SPSS $=$ Statistical Package for the Social Sciences

NPL $=$ Non Performing Loan

$\mathrm{NCBs}=$ Nationalized Commercial Banks

DFIs $=$ Development Financial Institutions

GDP $=$ Gross Domestic Product

NPAs $=$ Non Performing Assets

$\mathrm{SBI}=$ State Bank of India

$\mathrm{ROA}=$ Return on Assets

$\mathrm{ROI}=$ Return on Investment

$\mathrm{BB}=$ Bangladesh Bank

$\mathrm{BD}=$ Bangladesh

$\mathrm{BDT}=$ Bangladeshi Taka

$\mathrm{FY}=$ Fiscal Year

$\mathrm{LR}=$ Liquidity Ratio

$\mathrm{CAR}=$ Capital Adequacy Ratio

$\mathrm{TA}=$ Total Assets 